\title{
Habitually Late Bedtime is Associated With Elevated Serum Uric Acid and Monosodium Urate Monohydrate Deposition in Patients With Gout: A Case Control Study
}

\section{Xiaoting Chen}

Shanghai Jiao Tong University Affiliated Sixth People's Hospital

Lihui Chen

Shanghai Jiao Tong University Affiliated Sixth People's Hospital

Fengjing Liu

Shanghai Jiao Tong University Affiliated Sixth People's Hospital

\section{Si Chen}

Shanghai Jiao Tong University Affiliated Sixth People's Hospital

\section{Ying Han}

Shanghai Jiao Tong University Affiliated Sixth People's Hospital

\section{Zhumeng Hu}

Shanghai Jiao Tong University Affiliated Sixth People's Hospital

Haibing Chen ( $\square$ chenhb@sjtu.edu.cn)

Shanghai Jiao Tong University Affiliated Sixth People's Hospital https://orcid.org/0000-0002-2259-5522

\section{Research article}

Keywords: Late bedtime, Gout, MSU deposition, Ultrasound

Posted Date: June 18th, 2020

DOI: https://doi.org/10.21203/rs.3.rs-36001/v1

License: (c) (1) This work is licensed under a Creative Commons Attribution 4.0 International License. Read Full License 


\section{Abstract}

Background: In this study, we observed whether habitually late bedtime affects serum uric acid levels and monosodium urate monohydrate deposition in joints and tendons in patients with gout.

Methods: This study included 195 patients with gout, who had been divided into two groups based on their bedtime (early or late) and compared serum uric acid levels between the groups. The study also compared ultrasounds of joints and tendons between groups, including the metatarsal-phalangeal joints, knee joints, and tendons of the lower limbs. A multivariate logistic regression was used to analyse the risk factors of monosodium urate monohydrate deposition.

Results: Compared to patients with an early bedtime, those with a late bedtime had higher urate levels and a significantly higher proportion of double contour signs, tophi, and bone erosion in metatarsal-phalangeal joints $(p<$ 0.05). Late-bedtime patients also had higher proportions of synovial hypertrophy and double contour signs in knee joints $(p<0.05)$, and a higher incidence of tophi in the quadriceps tendon $(6.4 \%)$, compared to early-bedtime patients $(2.5 \% ; p<0.05)$. Late bedtime was associated with monosodium urate monohydrate deposition.

Conclusions: Patients with gout who had a late bedtime exhibited elevated urate levels, enhanced monosodium urate monohydrate deposition, and greater gout-related joint damage, compared to patients with an early bedtime.

\section{Background}

Uric acid is produced in the liver as the end product of purine metabolism, then excreted through the kidney. Elevated serum urate levels, or hyperuricaemia, occur when urate concentrations exceed $7 \mathrm{mg} / \mathrm{dL}$ in men or $6 \mathrm{mg} / \mathrm{dL}$ in women(1). Chronically elevated urate levels can create monosodium urate monohydrate (MSU) and be deposited into joints, where they cause joint inflammation and severe joint pain(2). The prevalences of hyperuricaemia and gout have significantly increased in recent years; these conditions are associated with unhealthy lifestyle habits such as the excessive intake of alcohol or fructose. Thus, other lifestyle habits presumably might also affect hyperuricaemia and gout(3).

Late bedtime is a poor sleep habit and is considered an emerging risk factor for various metabolic diseases. Sleep quality, duration, and bedtime are closely related to metabolic diseases such as hyperuricemia, diabetes, hypertension, and dyslipidaemia $(4,5)$. For example, rotating shift workers often have elevated urate levels (6-9). Qian(10) also found a significant association between bedtime and serum metabolites, such as uric acid and adenosine.

Chronically elevated urate causes the deposition of MSU into skeletal and muscular systems, inducing serious damage to the articular surface and affecting its function. This leads to gouty osteoarthritis in patients with hyperuricaemia or gout. Gouty arthritis often occurs in the lower limbs, mainly in the first metatarsophalangeal (MTP) joint. Bone tissue under the articular cartilage can also be gradually affected without treatment. Most studies thus far have measured the effects of sleep habits on urate levels; however, further investigation is needed regarding whether poor sleep habits affect MSU deposition and joint damage7-8.

Ultrasound (US) imaging is an effective method for detection of musculoskeletal involvement in various joint diseases $(11,12)$. In patients with hyperuricaemia or gout, US can detect joint inflammation, MSU deposition in cartilage ('double contour sign'), cartilage destruction, tophi, and bone erosion(13). Double contour signs and tophi are specific US manifestations of MSU deposition in patients with gouty arthritis(14). The double contour sign is the manifestation of MSU deposition on the joint surface; tophi is a granuloma-like substance formed by MSU wrapped in monocytes. Synovial hypertrophy, synovial effusion, and bone erosion are complications of gout. Compared with other imaging methods, the advantages of US include low ionising radiation, low cost, and easy access(15). Furthermore, US can 
identify the pathological features of different types of arthritis, and is a convenient and effective tool for diagnosis and management of gouty arthritis(16). This study analysed whether habitually late bedtimes affect urate levels, joints, and muscles in patients with gout.

\section{Methods}

\section{Patients}

The study was performed on 195 male patients between 20 and 65 years old diagnosed with gout in the Department of Endocrinology and Metabolism in Sixth People's Hospital affiliated to Shanghai Jiao Tong University (Shanghai, China) from September 2018 to September 2019. All patients were subjected to US examination according to the diagnostic criteria of the 2015 American College of Rheumatology / European Rheumatology Alliance (17). The study was approved by the Ethics Committee of the Sixth People's Hospital affiliated to Shanghai Jiaotong University and informed consent was obtained from all participants.

Enrolled patients were required to complete a self-report questionnaire. In this questionnaire, we defined 'habitually late bedtime' as sleeping after midnight over 3 days/week, either for study, work or entertainment $(18,19)$. All patients were divided into early bedtime group and late bedtime group.

\section{Clinical and laboratory assessments}

Clinical biochemical parameters were obtained by assessments of fasting vein blood samples, including blood routine, alanine aminotransferase, aspartate aminotransferase, blood lipids, blood uric acid, urate, creatinine, blood glucose, glycosylated hemoglobin and so on. At the same time, patients were required to provide 24-hour urine samples to detect glomerular filtration rate and uric acid excretion indicators. Glomerular filtration rate: GFR $(\mathrm{ml} / \mathrm{min} / 1.73 \mathrm{~m} 2)=$ $186.3 \times$ (serum creatinine [umol/L]/88.4)-1.154 $\times$ (age [year])-0.203 $\times(0.742$ for women). Uric acid clearance rate (CUA $[\mathrm{ml} / \mathrm{min}])=$ urine volume/minute $(\mathrm{ml} / \mathrm{min}) \times$ urine uric acid $(\mathrm{mg}) * 1000 /$ serum uric acid $(\mathrm{mg})$.

\section{Ultrasonic assessment}

The ultrasound examination used Aplio 500 (Toshiba) as we previously described (19), which is equipped with a multi-frequency linear transducer (12-14 MHz). For each joint or tendon, the ultrasound evaluation criteria are: (1) synovial hypertrophy: synovial hyperplasia exceeds the highest connection point of the bone surface; joint effusion: the joint cavity widens, showing anechoic or hypoechoic; (2) Double-counter sign: high echo over the edge of articular cartilage, showing irregular continuous or intermittent strips; (3) hyperechoic spots: bright spots in the tendon. Reducing the gain can detect hyperechoic structures; (4) tophi: manifested as a low-echo or high-echo mass surrounded by a small anechoic rim, located in the joint or tendon; (5) bone erosion: non-physiologic interruption of the cortical bone margin, that can be detected on the verticawumianl section $(17,19)$. The bilateral knee, ankle and MTPs joints were routinely scanned.

\section{Statistical analysis}

The describe categorical data was expressed in frequencies (expressed as percentages), the measurement data was expressed in Mean \pm SD. The mean of the two groups was compared by Student's t-test, the frequency of the describe categorical data was compared by $\chi 2$ test, and $P$ values less than 0.05 were considered statistically significant. $A$ 
forward stepwise logistic regression method was used to analyze the correlation between multiple factors and MSU deposition. All analyses were two-tailed and were performed using SPSS 23.0.

\section{Results}

\section{Patients' urate levels and clinical characteristics}

Age-matched male patients with gout $(n=195)$ were included in this study; among them, 101 patients typically had a late bedtime and 94 patients typically had an early bedtime. Patients with a late bedtime had significantly higher urate levels $(557.7 \pm 76.8 \mu \mathrm{mol} / \mathrm{L})$, total cholesterol $(5.2 \pm 0.8 \mathrm{mmol} / \mathrm{L} \mathrm{vs})$, and high-sensitivity C-reactive protein (CRP; $4.9 \pm$ $7.9 \mathrm{mg} / \mathrm{L}$ ), compared to patients with early bedtimes (urate $=525.6 \pm 71.1 \mu \mathrm{mol} / \mathrm{L} ; \mathrm{p}<0.01$; total cholesterol $=4.9 \pm 0.8$ $\mathrm{mmol} / \mathrm{L} ; \mathrm{p}<0.05 ; \mathrm{CRP}=2.8 \pm 5.2 \mathrm{mg} / \mathrm{L} ; \mathrm{p}<0.05 ;$ Table 1$)$.

\section{Ultrasound manifestations in joints and tendons}

US manifestations in joints were compared between the two groups. Of the 202 MTP joints, the proportion of doublecontour signs was significantly higher in late-bedtime patients $(29.7 \%)$ than in early-bedtime patients $(19.7 \%$; $p<0.05)$. The proportion of tophi was significantly higher in late-bedtime patients (23.8\%) than in early-bedtime patients (15.4\%; $p$ $<0.05$; Table 2). The proportion of double contour signs in knee joints was also higher in patients with a late bedtime $(21.3 \%)$ than in patients with an early bedtime $(13.3 \% ; p<0.05)$.

MSU deposition is also found in tendons, where it can destroy tendon structure, restrict joint movement, and cause tenosynovitis and joint stiffness. Hyperechoic spots and tophi in tendons are indicators of MSU deposition (12). Our study found that hyperechoic spots and tophi were mainly present in the quadriceps and patellar tendons (Table 3); the proportion of tophi in the quadriceps tendons was significantly higher in the late bedtime group (6.4\%) than in the early bedtime group $(2.5 \% ; \mathrm{p}<0.05)$. In addition, tophi were present in the posterior-tibial tendons of two late-bedtime patients and in the peroneus tendon in another late-bedtime patient.

The proportion of synovial effusion was lower in the late bedtime group (47.5\%) than in the early bedtime group (62.2\%; $p<0.01$; Table 2). Synovial hypertrophy did not differ between the two groups. Bone erosion, suggesting the destruction of bone tissue in the joints, was significantly lower in the MTP joints of late-bedtime patients (21.2\%) than in the MTP joints of early-bedtime patients (30.7\%; $p<0.05)$. In the knee joints, 12 joints $(5.9 \%)$ of late bedtime patients showed synovial hypertrophy, compared with 3 joints in early bedtime patients $(1.6 \% ; p<0.05)$. In addition, the abovementioned pathological US manifestations in joints were more serious in patients who had been diagnosed with gout for $>5$ years.

\section{Analysis of factors associated with MSU deposition}

Patients were divided into two groups according to the presence or absence of MSU deposition in the joints or tendons (Table 4). Nine factors were found to significantly differ between the two groups: age, duration of gout, urate levels, uric acid clearance, habitually late bedtime, history of urate-lowering medication, anodyne treatment, erythrocyte sedimentation rate, and CRP $(p<0.05)$. Multivariate logistic regression was used to identify factors associated with MSU deposition; the results are shown in Table 5. The duration of gout, CRP, and habitually late bedtime were positively associated with MSU accumulation. These results are consistent with our hypothesis that bedtime is an important mediator of MSU deposition. 


\section{Discussion}

This study analysed the effects of habitually late bedtime on urate levels and MSU deposition in patients with gout. Patients with gout who had a late bedtime exhibited higher urate levels and more MSU accumulation, compared to patients with an early bedtime. MSU deposition in MTP and knee joints was more severe in patients who had gout for $>5$ years. In addition, MSU deposition was independently associated with the duration of gout, CRP, and habitually late bedtime.

A late bedtime can increase circulating uric acid levels. There is a positive relationship between bedtime and urate levels in long-term shift workers, who have elevated urate levels $(3,9)$. In this study, we found that patients with gout also had elevated urate levels. Elevated uric acid levels that exceed the level of solubility during circulation cause the formation of MSU. However, in vitro experiments could not simulate the formation and deposition of MSU crystals using high concentrations of a uric acid solution; thus, other factors presumably promote the formation and deposition of MSU in vivo(20). In our study, the manifestations of double-contour signs and tophi were more severe in the joints or tendons of late-bedtime patients. A late bedtime is an independent risk factor that affects MSU deposition, suggesting that elevated urate levels and habitually late bedtime may synergistically promote MSU deposition in patients with gout.

Temperature, $\mathrm{pH}$, and trauma all promote MSU deposition. In addition, recent studies suggest that humoral immunity and poor blood supply contribute to the formation and deposition of MSU. Kanevets(21) found that immunoglobulin (Ig) M and IgG in the synovial fluid of patients with gout bind to MSU crystals and promote the formation of urate crystals in vitro. Kaneko (22)also found that $\gamma$-globulin promotes MSU crystal formation in vitro. These findings suggest that humoral immunity is involved in MSU formation and deposition. Sleep deprivation, late bedtime, and reduced sleep time activate the immune system and alter serum humoral immune parameters. For example, circulating $\lg G, \lg A$ and IgM levels are significantly elevated in patients with chronic sleep disturbances(23). The biological processes involved in MSU crystal formation are not yet clear; further analysis is needed regarding whether humoral immune changes caused by poor sleep habits stimulate the formation and deposition of MSU crystals. In addition, preferential deposition in tissues with minimal vascularisation (e.g., tendons, ligaments, and cartilage) implies that sleep quality has a profound effect on vascular function(24). Sleep deprivation can impair the function of vascular endothelial cells by inducing sympathetic nervous system activation, systemic inflammation, or oxidative stress; these changes reduce blood supply to tissues, which may increase MSU deposition(25). Thus far, there have been few studies regarding the relationship of poor sleep habits with vascular dysfunction and MSU deposition; further research is needed.

Synovial hypertrophy, synovial effusion, and bone erosion are complications of gout. Synovial hypertrophy and effusion are common symptoms of joint inflammation, and chronic inflammation is associated with disease progression. Bone erosion in the late stage of many joint diseases functionally damages the skeletal system(26). Our study found that MTP joint and bone erosion was significantly higher in late-bedtime patients than in early-bedtime patients. In a previous study, we found that age, duration of gout, and numbers of tophi and synovial hypertrophies are factors that affect bone erosion. Longer gout persistence is associated with a greater number of tophi and higher incidence of bone erosion (19). Inflammatory cytokines are also associated with bone erosion. MSU can promote the expression and secretion of various pro-inflammatory molecules, including CRP, tumour necrosis factor a, interleukin (IL) 1, IL-6, IL-17, and macrophage colony-stimulating factor. These cytokines can promote the expression of receptor activator of NF-kB ligand, which enhances osteoclast differentiation and activity, ultimately causing joint destruction(25). Long-term insomnia can also lead to inflammation and elevated transcription of inflammatory factors such as CRP, IL-1 $\beta$, IL-6, and IL-17(26). Our study revealed elevated CRP levels in late-bedtime patients, consistent with the findings in previous studies. In addition, patients with late bedtimes had more severe MSU deposition in joints and tendons; these factors may be responsible for increasing bone erosion. 
This study had certain limitations: the number of patients was relatively small and should be increased in future investigations; parameters such as sleep duration and both mental and physical states at bedtime require further evaluation with respect to the relationship of sleep with uric acid levels and gout.

\section{Conclusion}

In conclusion, this study showed that patients with a habitually late bedtime had higher serum uric acid levels and more MSU deposition in joints and tendons, compared to patients with an early bedtime. Additionally, gout-related joint damage was more severe in late-bedtime patients. Habitually late bedtime was independently associated with MSU deposition, which implies that improvement of sleeping habits may help control urate levels and reduce gout-related complications in patients with sleep disorders.

\section{Abbreviations}

MSU: Monosodiumurate; MTP:Metatarsophalangeal; US: Ultrasound;BMI: Body mass index; GFR: Glomerular filtration rate;CUA: Uric acid clearance rate; SD: Standard deviation; CRP: C-reactive protein.

\section{Declarations}

\section{Competing Interest}

The authors declare that they have no competing interests.

\section{Authors' contributions}

Study conception and design were performed by HC,XC, LC; acquisition of data was done by XC, LC, FL, SC, YH and ZH; analysis and interpretation of data were performed by XC, LC, FL, SC, YH, ZHand HC. HC had full access to all of the data in the study and takes responsibility for the integrity of the data and the accuracy of the data analysis. All authors were involved in drafting the manuscript or revising it critically for important intellectual content. All authors read and approved the final manuscript.

\section{Ethics approval and consent to participate}

The study is approved by the Ethics Committee of Shanghai Sixth People's Hospital (Approval No: 2018-102)

\section{Consent for publication}

\section{Not applicable.}

\section{Availability of data and materials}

The datasets used and/or analyzed during the current study are available from the corresponding author on reasonable request. 


\section{Acknowledgments}

The authors thank all team members and participants from Shanghai Jiaotong University Affiliated Sixth People's Hospital.

\section{Funding}

This work was supported by National Key Research and Development Program of China[grant number 2019YFA0904500] and the National Natural Science Foundation of China [grant numbers 81670737, 81870616].

\section{References}

1. Bardin T, Richette P. Definition of hyperuricemia and gouty conditions. Current opinion in rheumatology. 2014;26(2):186-91.

2. Terkeltaub R. Update on gout: new therapeutic strategies and options. Nature reviews Rheumatology. 2010;6(1):308.

3. Li C, Hsieh MC, Chang SJ. Metabolic syndrome, diabetes, and hyperuricemia. Current opinion in rheumatology. 2013;25(2):210-6.

4. Seo JA, Lee DY, Yu JH, Cho H, Lee SK, Suh S, et al. Habitual late sleep initiation is associated with increased incidence of type 2 diabetes mellitus in Korean adults: the Korean Genome and Epidemiology Study. Sleep. 2019;42(7).

5. Stranges S, Dorn JM, Cappuccio FP, Donahue RP, Rafalson LB, Hovey KM, et al. A population-based study of reduced sleep duration and hypertension: the strongest association may be in premenopausal women. J Hypertens. 2010;28(5):896-902.

6. Kawada T, Otsuka T. Effect of shift work on the development of metabolic syndrome after 3 years in Japanese male workers. Arch Environ Occup Health. 2014;69(1):55-61.

7. Uetani M, Sakata K, Oishi M, Tanaka K, Nakada S, Nogawa K, et al. The influence of being overweight on the relationship between shift work and increased total cholesterol level. Ann Epidemiol. 2011;21(5):327-35.

8. Sookoian S, Gemma C, Fernández Gianotti T, Burgueño A, Alvarez A, González CD, et al. Effects of rotating shift work on biomarkers of metabolic syndrome and inflammation. J Intern Med. 2007;261(3):285-92.

9. Oh JS, Choi WJ, Lee MK, Han SW, Song SH, Yun JW, et al. The association between shift work and hyperuricemia in steelmaking male workers. Ann Occup Environ Med. 2014;26(1):42.

10. Xiao Q, Derkach A, Moore SC, Zheng W, Shu XO, Gu F, et al. Habitual Sleep and human plasma metabolomics. Metabolomics. 2017;13(5).

11. Wright SA, Filippucci E, McVeigh C, Grey A, McCarron M, Grassi W, et al. High-resolution ultrasonography of the first metatarsal phalangeal joint in gout: a controlled study. Ann Rheum Dis. 2007;66(7):859-64.

12. Pineda C, Amezcua-Guerra LM, Solano C, Rodriguez-Henríquez P, Hernández-Díaz C, Vargas A, et al. Joint and tendon subclinical involvement suggestive of gouty arthritis in asymptomatic hyperuricemia: an ultrasound controlled study. Arthritis Res Ther. 2011;13(1):R4.

13. Chowalloor PV, Keen HI. A systematic review of ultrasonography in gout and asymptomatic hyperuricaemia. Ann Rheum Dis. 2013;72(5):638-45.

14. Kaneko K, Maru M. Determination of urate crystal formation using flow cytometry and microarea X-ray diffractometry. Anal Biochem. 2000;281(1):9-14. 
15. Ottaviani S, Bardin T, Richette P. Usefulness of ultrasonography for gout. Joint Bone Spine. 2012;79(5):441-5.

16. Naredo E, Uson J, Jiménez-Palop M, Martínez A, Vicente E, Brito E, et al. Ultrasound-detected musculoskeletal urate crystal deposition: which joints and what findings should be assessed for diagnosing gout? Ann Rheum Dis. 2014;73(8):1522-8.

17. Weisman MH. Imaging in Rheumatic Diseases. Rheum Dis Clin North Am. 2016;42(4):xiii.

18. Ghaemi-Oskouie F, Shi Y. The role of uric acid as an endogenous danger signal in immunity and inflammation. Curr Rheumatol Rep. 2011;13(2):160-6.

19. Kanevets U, Sharma K, Dresser K, Shi Y. A role of IgM antibodies in monosodium urate crystal formation and associated adjuvanticity. J Immunol. 2009;182(4):1912-8.

20. Besedovsky L, Lange T, Born J. Sleep and immune function. Pflugers Arch. 2012;463(1):121-37.

21. Abate M, Schiavone C, Salini V, Andia I. Occurrence of tendon pathologies in metabolic disorders. Rheumatology (Oxford). 2013;52(4):599-608.

22. Grassi D, Socci V, Tempesta D, Ferri C, De Gennaro L, Desideri G, et al. Flavanol-rich chocolate acutely improves arterial function and working memory performance counteracting the effects of sleep deprivation in healthy individuals. J Hypertens. 2016;34(7):1298-308.

23. Dalbeth N, Clark B, Gregory K, Gamble G, Sheehan T, Doyle A, et al. Mechanisms of bone erosion in gout: a quantitative analysis using plain radiography and computed tomography. Ann Rheum Dis. 2009;68(8):1290-5.

24. Wu M, Liu FJ, Chen J, Chen L, Wei C, Hu ZM, et al. Prevalence and Factors Associated With Bone Erosion in Patients With Gout. Arthritis Care Res (Hoboken). 2019;71(12):1653-9.

25. Schlesinger N, Thiele RG. The pathogenesis of bone erosions in gouty arthritis. Ann Rheum Dis. 2010;69(11):190712.

26. Irwin MR, Witarama T, Caudill M, Olmstead R, Breen EC. Sleep loss activates cellular inflammation and signal transducer and activator of transcription (STAT) family proteins in humans. Brain Behav Immun. 2015;47:86-92.

\section{Tables}


Table 1.

Comparison of clinical characteristics between patients with or without habitually late bedtime

\begin{tabular}{|c|c|c|c|}
\hline & Early bedtime & Late bedtime & $P$ \\
\hline $\mathrm{N}$ & 94 & 101 & \\
\hline Age, yaer & $45.0 \pm 12.2$ & $42.6 \pm 11.8$ & $>0.05$ \\
\hline Sweet drink & $13(13.8 \%)$ & $22(21.8 \%)$ & $>0.05$ \\
\hline Smoking, n (\%) & $33(35.1 \%)$ & $41(40.6 \%)$ & $>0.05$ \\
\hline Alcohol drinking, n (\%) & $34(36.2 \%)$ & $37(36.6 \%)$ & $>0.05$ \\
\hline BMI, kg/m² & $26.0 \pm 3.4$ & $26.7 \pm 3.1$ & $>0.05$ \\
\hline Waist hip ratio & $0.94 \pm 0.06$ & $0.95 \pm 0.06$ & $>0.05$ \\
\hline CRP, mg/liter & $2.8 \pm 5.2$ & $4.9 \pm 7.9$ & 0.04 \\
\hline ESR, mm/hour & $7.9 \pm 10.1$ & $9.9 \pm 9.7$ & $>0.05$ \\
\hline Systolic BP, mmHg & $130.6 \pm 17.6$ & $135.9 \pm 20.2$ & $>0.05$ \\
\hline Diastolic BP, mmHg & $85.8 \pm 12.8$ & $87.9 \pm 12.5$ & $>0.05$ \\
\hline$A L T, U / L$ & $36.9 \pm 27.1$ & $39.6 \pm 25.2$ & $>0.05$ \\
\hline Y-Glutamyltransferase, U/L & $49.9 \pm 46.2$ & $56.3 \pm 45.5$ & $>0.05$ \\
\hline Triglyceride, $\mathrm{mmol} / \mathrm{L}$ & $2.3 \pm 1.4$ & $2.7 \pm 1.4$ & $>0.05$ \\
\hline Total cholesterol, $\mathrm{mmol} / \mathrm{L}$ & $4.9 \pm 0.8$ & $5.2 \pm 0.8$ & 0.03 \\
\hline urate, umol/L & $525.6 \pm 71.1$ & $557.7 \pm 76.8$ & 0.003 \\
\hline CUA, $\mathrm{ml} / \mathrm{min}$ & $4.6 \pm 2.0$ & $4.2 \pm 2.0$ & $>0.05$ \\
\hline Estimated GFR, $\mathrm{ml} / \mathrm{min} / 1.73 \mathrm{~m}^{2}$ & $88.5 \pm 21.2$ & $90.1 \pm 18.3$ & $>0.05$ \\
\hline Fasting plasma glucose, $\mathrm{mmol} / \mathrm{L}$ & $5.6 \pm 0.8$ & $5.6 \pm 0.9$ & $>0.05$ \\
\hline Glycosylated hemoglobin, \% & $5.6 \pm 0.5$ & $5.7 \pm 0.6$ & $>0.05$ \\
\hline Duration of gout, year & $5.7 \pm 6.1$ & $6.2 \pm 6.3$ & $>0.05$ \\
\hline \multicolumn{4}{|l|}{ Medication history, n (\%) } \\
\hline Urate-lowering therapy & $17 \rrbracket 18.1 \% \rrbracket$ & $24 \llbracket 23.7 \% \rrbracket$ & $>0.05$ \\
\hline Anodyne therapy & $13 \otimes 13.8 \% \bigotimes$ & $23 \rrbracket 22.8 \% \rrbracket$ & $>0.05$ \\
\hline \multicolumn{4}{|c|}{$\begin{array}{l}\text { Continuous variables are mean } \pm \mathrm{SD} \text { unless indicated. Frequencies were expressed as percentages. } \mathrm{BMI}=\text { body } \\
\text { mass index; } \mathrm{CRP}=\mathrm{C} \text {-reactive protein; } \mathrm{ESR}=\text { erythrocyte sedimentation rate; } \mathrm{BP}=\text { blood pressure; } \mathrm{ALT}=\text { ala- nine } \\
\text { aminotransferase; urate= serum uric acid; } \mathrm{CUA}=\text { uric acid clearance rate; } \mathrm{GFR}=\text { glomerular filtration rate. }\end{array}$} \\
\hline
\end{tabular}


Table 2

Ultrasound manifestations of MTPs, knee and ankle joints

\begin{tabular}{|c|c|c|c|c|c|c|c|c|c|}
\hline & \multicolumn{3}{|c|}{ Duration of gout $<=5$ years } & \multicolumn{3}{|c|}{ Duration of gout $>5$ years } & \multicolumn{3}{|l|}{ Total } \\
\hline & $\begin{array}{l}\text { Early } \\
\text { bedtime } \\
(n=112)\end{array}$ & $\begin{array}{l}\text { Late } \\
\text { bedtime }(n=126)\end{array}$ & $P$ & $\begin{array}{l}\text { Early } \\
\text { bedtime } \\
(n=76)\end{array}$ & $\begin{array}{l}\text { Late } \\
\text { bedtime } \\
(n=76)\end{array}$ & $P$ & $\begin{array}{l}\text { Early } \\
\text { bedtime } \\
(n=188)\end{array}$ & $\begin{array}{l}\text { Late } \\
\text { bedtime } \\
(n=202)\end{array}$ & $P$ \\
\hline \multicolumn{10}{|l|}{$\begin{array}{l}\text { MTP joints, } \\
n(\%)\end{array}$} \\
\hline $\begin{array}{l}\text { Synovial } \\
\text { fluid }\end{array}$ & $\begin{array}{l}73 \\
(65.2 \%)\end{array}$ & $\begin{array}{l}63 \\
(50.0 \%)\end{array}$ & 0.018 & $\begin{array}{l}44 \\
(57.9 \%)\end{array}$ & $\begin{array}{l}33 \\
(42.3 \%)\end{array}$ & 0.870 & $\begin{array}{l}117 \\
(62.2 \%)\end{array}$ & $\begin{array}{l}96 \\
(47.5 \%)\end{array}$ & 0.004 \\
\hline $\begin{array}{l}\text { Synovial } \\
\text { hypertrophy }\end{array}$ & $\begin{array}{l}45 \\
(40.2 \%)\end{array}$ & $\begin{array}{l}59 \\
(46.8 \%)\end{array}$ & 0.302 & $\begin{array}{l}37 \\
(48.7 \%)\end{array}$ & $\begin{array}{l}47 \\
(61.8 \%)\end{array}$ & 0.103 & $\begin{array}{l}82 \\
(43.6 \%)\end{array}$ & $\begin{array}{l}106 \\
(52.5 \%)\end{array}$ & 0.080 \\
\hline $\begin{array}{l}\text { Double- } \\
\text { counter } \\
\text { sign }\end{array}$ & $\begin{array}{l}15 \\
(13.4 \%)\end{array}$ & $\begin{array}{l}26 \\
(20.6 \%)\end{array}$ & 0.140 & $\begin{array}{l}22 \\
(28.9 \%)\end{array}$ & $\begin{array}{l}34 \\
(44.7 \%)\end{array}$ & 0.010 & $\begin{array}{l}37 \\
(19.7 \%)\end{array}$ & $\begin{array}{l}60 \\
(29.7 \%)\end{array}$ & 0.022 \\
\hline Tophi & $\begin{array}{l}5 \\
(4.5 \%)\end{array}$ & $\begin{array}{l}7 \\
(5.6 \%)\end{array}$ & 0.701 & $\begin{array}{l}24 \\
(31.6 \%)\end{array}$ & $\begin{array}{l}41 \\
(53.9 \%)\end{array}$ & 0.005 & $\begin{array}{l}29 \\
(15.4 \%)\end{array}$ & $\begin{array}{l}48 \\
(23.8 \%)\end{array}$ & 0.039 \\
\hline $\begin{array}{l}\text { Bone } \\
\text { erosion }\end{array}$ & $\begin{array}{l}12 \\
(11.6 \%)\end{array}$ & $15(11.9 \%)$ & 0.943 & $\begin{array}{l}28 \\
(36.8 \%)\end{array}$ & $\begin{array}{l}47 \\
(61.8 \%)\end{array}$ & 0.002 & $\begin{array}{l}40 \\
(21.2 \%)\end{array}$ & $\begin{array}{l}62 \\
(30.7 \%)\end{array}$ & 0.037 \\
\hline \multicolumn{10}{|l|}{$\begin{array}{l}\text { Knee joints, } \\
\text { n (\%) }\end{array}$} \\
\hline $\begin{array}{l}\text { Synovial } \\
\text { fluid }\end{array}$ & $\begin{array}{l}32 \\
(28.6 \%)\end{array}$ & $27(22.2 \%)$ & 0.26 & $\begin{array}{l}43 \\
(55.3 \%)\end{array}$ & $\begin{array}{l}41 \\
(55.3 \%)\end{array}$ & 0.744 & $\begin{array}{l}75 \\
(39.8 \%)\end{array}$ & $\begin{array}{l}68 \\
(33.7 \%)\end{array}$ & 0.202 \\
\hline $\begin{array}{l}\text { Synovial } \\
\text { hypertrophy }\end{array}$ & $\begin{array}{l}1 \\
(0.9 \%)\end{array}$ & $\begin{array}{l}2 \\
(1.6 \%)\end{array}$ & 1.000 & $\begin{array}{l}2 \\
(2.6 \%)\end{array}$ & $\begin{array}{l}10 \\
(13.2 \%)\end{array}$ & 0.031 & $\begin{array}{l}3 \\
(1.6 \%)\end{array}$ & $\begin{array}{l}12 \\
(5.9 \%)\end{array}$ & 0.03 \\
\hline $\begin{array}{l}\text { Double- } \\
\text { counter } \\
\text { sign }\end{array}$ & $\begin{array}{l}8 \\
(7.1 \%)\end{array}$ & $11(8.7 \%)$ & 0.652 & $\begin{array}{l}17 \\
(22.4 \%)\end{array}$ & $\begin{array}{l}32 \\
(42.1 \%)\end{array}$ & 0.009 & $\begin{array}{l}25 \\
(13.3 \%)\end{array}$ & $\begin{array}{l}43 \\
(21.3 \%)\end{array}$ & 0.038 \\
\hline Tophi & $\begin{array}{l}5 \\
(4.5 \%)\end{array}$ & $\begin{array}{l}2 \\
(1.6 \%)\end{array}$ & 0.259 & $\begin{array}{l}13 \\
(17.1 \%)\end{array}$ & $\begin{array}{l}20 \\
(26.3 \%)\end{array}$ & 0.168 & $\begin{array}{l}15 \\
(8.0 \%)\end{array}$ & $\begin{array}{l}25 \\
(12.4 \%)\end{array}$ & 0.153 \\
\hline $\begin{array}{l}\text { Bone } \\
\text { erosion }\end{array}$ & $\begin{array}{l}2 \\
(1.8 \%)\end{array}$ & $\begin{array}{l}2 \\
(1.6 \%)\end{array}$ & 0.905 & $\begin{array}{l}10 \\
(13.2 \%)\end{array}$ & $\begin{array}{l}18 \\
(23.7 \%)\end{array}$ & 0.094 & $\begin{array}{l}12 \\
(6.4 \%)\end{array}$ & $\begin{array}{l}20 \\
(9.9 \%)\end{array}$ & 0.206 \\
\hline $\begin{array}{l}\text { Ankle } \\
\text { joints, n (\%) }\end{array}$ & & & & & & & & & \\
\hline $\begin{array}{l}\text { Synovial } \\
\text { fluid }\end{array}$ & $\begin{array}{l}15 \\
(13.4 \%)\end{array}$ & $\begin{array}{l}16 \\
(12.7 \%)\end{array}$ & 0.874 & $\begin{array}{l}18 \\
(23.7 \%)\end{array}$ & $\begin{array}{l}16 \\
(21.1 \%)\end{array}$ & 0.697 & $\begin{array}{l}33 \\
(17.6 \%)\end{array}$ & $\begin{array}{l}32 \\
(15.8 \%)\end{array}$ & 0.650 \\
\hline $\begin{array}{l}\text { Synovial } \\
\text { hypertrophy }\end{array}$ & $\begin{array}{l}8 \\
(7.1 \%)\end{array}$ & $\begin{array}{l}3 \\
(2.4 \%)\end{array}$ & 0.121 & $\begin{array}{l}8 \\
(10.5 \%)\end{array}$ & $\begin{array}{l}14 \\
(18.4 \%)\end{array}$ & 0.167 & $\begin{array}{l}16 \\
(8.5 \%)\end{array}$ & $\begin{array}{l}17 \\
(8.4 \%)\end{array}$ & 0.973 \\
\hline
\end{tabular}




\begin{tabular}{|c|c|c|c|c|c|c|c|c|c|}
\hline $\begin{array}{l}\text { Double- } \\
\text { counter } \\
\text { sign }\end{array}$ & $\begin{array}{l}12 \\
(10.7 \%)\end{array}$ & $\begin{array}{l}14 \\
(11.1 \%)\end{array}$ & 0.922 & $\begin{array}{l}16 \\
(21.1 \%)\end{array}$ & $\begin{array}{l}22 \\
(28.9 \%)\end{array}$ & 0.261 & $\begin{array}{l}28 \\
(14.9 \%)\end{array}$ & $\begin{array}{l}36 \\
(17.8 \%)\end{array}$ & 0.435 \\
\hline Tophi & $\begin{array}{l}7 \\
(6.3 \%)\end{array}$ & $\begin{array}{l}4 \\
(3.2 \%)\end{array}$ & 0.357 & $\begin{array}{l}10 \\
(13.2 \%)\end{array}$ & $\begin{array}{l}20 \\
(25.0 \%)\end{array}$ & 0.063 & $\begin{array}{l}17 \\
(9.0 \%)\end{array}$ & $\begin{array}{l}21 \\
(9.7 \%)\end{array}$ & 0.652 \\
\hline $\begin{array}{l}\text { Bone } \\
\text { erosion }\end{array}$ & $\begin{array}{l}8 \\
(7.1 \%)\end{array}$ & $\begin{array}{l}3 \\
(2.4 \%)\end{array}$ & 0.121 & $\begin{array}{l}21 \\
(27.6 \%)\end{array}$ & $\begin{array}{l}25 \\
(32.9 \%)\end{array}$ & 0.480 & $\begin{array}{l}29 \\
(15.4 \%)\end{array}$ & $\begin{array}{l}28 \\
(13.0 \%)\end{array}$ & 0.662 \\
\hline
\end{tabular}

Table 3.

Ultrasound manifestations in tendons

\begin{tabular}{|llll|}
\hline & $\begin{array}{l}\text { Early bedtime } \\
(\mathrm{n}=188)\end{array}$ & $\begin{array}{l}\text { Late bedtime } \\
(\mathrm{n}=202)\end{array}$ & $P$ \\
\hline Quadriceps tendon, $\mathbf{n}(\%)$ & & & \\
\hline hyperechoic spots & 0 & $2(1 \%)$ & $>0.05$ \\
\hline tophi & $5(2.5 \%)$ & $13(6.4 \%)$ & 0.039 \\
\hline Patellar tendon, $\mathbf{n}(\%)$ & & & \\
\hline hyperechoic spots & $5(2.7 \%)$ & $12(5.9 \%)$ & $>0.05$ \\
\hline tophi & $6(3.2 \%)$ & $9(4.5 \%)$ & $>0.05$ \\
\hline
\end{tabular}


Table 4

Comparison of multiple factors between patients with or without MSU deposition

\begin{tabular}{|c|c|c|c|}
\hline & Non-MSU deposition & MSU deposition & $P$ \\
\hline $\mathrm{N}$ & 87 & 108 & \\
\hline Age, year & $41.3 \pm 11.9$ & $45.8 \pm 11.8$ & 0.008 \\
\hline Sweet drink, n (\%) & $15(17.2 \%)$ & $20(18.5 \%)$ & $>0.05$ \\
\hline Smoking, n (\%) & $28(32.2 \%)$ & $46(42.6 \%)$ & $>0.05$ \\
\hline Drinking, n (\%) & $26(29.9 \%)$ & $45(41.7 \%)$ & $>0.05$ \\
\hline Late bedtime, n (\%) & $33 \rrbracket 37.9 \% \rrbracket$ & $68 \bowtie 63.0 \% \rrbracket$ & 0.001 \\
\hline $\mathrm{BMI}, \mathrm{kg} / \mathrm{m}^{2}$ & $26.6 \pm 3.2$ & $26.2 \pm 3.3$ & $>0.05$ \\
\hline Waist hip ratio & $0.94 \pm 0.05$ & $0.95 \pm 0.07$ & $>0.05$ \\
\hline CRP, mg/liter & $2.6 \pm 5.6$ & $5.0 \pm 7.4$ & 0.019 \\
\hline ESR, mm/hour & $7.3 \pm 8.6$ & $10.4 \pm 10.6$ & 0.033 \\
\hline Systolic BP, mmHg & $130.5 \pm 18.3$ & $135.7 \pm 19.6$ & $>0.05$ \\
\hline Diastolic BP, mmHg & $85.3 \pm 12.7$ & $88.2 \pm 12.3$ & $>0.05$ \\
\hline$A L T, U / L$ & $37.6 \pm 24.6$ & $38.8 \pm 27.4$ & $>0.05$ \\
\hline Y-Glutamyltransferase, U/L & $46.8 \pm 34.7$ & $58.5 \pm 52.5$ & $>0.05$ \\
\hline Triglyceride, $\mathrm{mmol} / \mathrm{L}$ & $2.4 \pm 1.3$ & $2.5 \pm 1.5$ & $>0.05$ \\
\hline Total cholesterol, mmol/L & $4.9 \pm 0.8$ & $5.1 \pm 0.8$ & $>0.05$ \\
\hline urate, umol/L & $522.4 \pm 63.4$ & $558.3 \pm 81.1$ & 0.001 \\
\hline CUA, ml/min & $4.8 \pm 1.7$ & $4.1 \pm 2.1$ & 0.010 \\
\hline eGFR, ml/min/1.73 $\mathrm{m}^{2}$ & $90.9 \pm 18.9$ & $87.9 \pm 20.4$ & $>0.05$ \\
\hline Fasting plasma glucose, $\mathrm{mmol} / \mathrm{L}$ & $5.6 \pm 0.8$ & $5.6 \pm 0.9$ & $>0.05$ \\
\hline Glycosylated hemoglobin, \% & $5.6 \pm 0.5$ & $5.6 \pm 0.6$ & $>0.05$ \\
\hline Duration of gout, year & $3.1 \pm 4.5$ & $8.3 \pm 6.4$ & 0.001 \\
\hline \multicolumn{4}{|l|}{ Medication history, n (\%) } \\
\hline Urate-lowering therapy & $11 \otimes 12.6 \% \bigotimes$ & $31 \rrbracket 28.7 \% \square$ & 0.007 \\
\hline Anodyne therapy & $8 \varangle 9.2 \% \rrbracket$ & $28 \varangle 25.9 \% \rrbracket$ & 0.003 \\
\hline
\end{tabular}


Table 5

Logistic regression analysis of factors associated with MSU deposition

\begin{tabular}{|llll|}
\hline Variable & $\beta$ coefficient & OR $(95 \% \mathrm{Cl})$ & $P$ \\
\hline Duration of gout & 0.164 & $1.178(1.093-1.269)$ & $<0.01$ \\
\hline Late bedtime & 0.503 & $1.654(1.152-2.376)$ & $<0.01$ \\
CRP & 0.142 & $1.152(1.010-1.315)$ & 0.035 \\
\hline CRP = C-reactive protein; OR = odds ratio; $95 \% \mathrm{Cl}=95 \%$ confidence interval. \\
\hline
\end{tabular}

